\title{
Formation of anoxia and denitrification in the bottom waters of a tropical estuary, southwest coast of India
}

\author{
G. D. Martin ${ }^{1,2}$, K. R. Muraleedharan ${ }^{1}$, J. G. Vijay ${ }^{1}$, G. Rejomon ${ }^{1}$, N. V. Madhu ${ }^{1}$, \\ A. Shivaprasad ${ }^{1}$, C. K. Haridevi ${ }^{1}$, M. Nair ${ }^{1}$, K. K. Balachandran ${ }^{1}$, \\ C. Revichandran ${ }^{1}$, K. V. Jayalakshmy ${ }^{1}$, and N. Chandramohanakumar ${ }^{2}$ \\ ${ }^{1}$ National Institute of Oceanography, Regional Centre, Kochi-682018, India \\ ${ }^{2}$ Dept. of Chemical Oceanography, Cochin University of Science and Technology, \\ Kochi-682016, India \\ Received: 23 February 2010 - Accepted: 3 March 2010 - Published: 15 March 2010 \\ Correspondence to: G. D. Martin (martinnio@gmail.com) \\ Published by Copernicus Publications on behalf of the European Geosciences Union.
}

\begin{abstract}
Hydrographic characteristics of the southwest coast of India and its adjoining Cochin backwaters (CBW) were studied during the summer monsoon period. Anomalous formation of anoxia and denitrification were observed in the bottom layers of CBW, which

5 have not been previously reported elsewhere in any tropical estuarine systems. The prevalent upwelling in the Arabian Sea (AS) brought cool, high saline, oxygen deficient and nutrient-rich waters towards the coastal zone and bottom layers of CBW during the high tide. High freshwater discharge in the surface layers brought high amount of nutrients and makes the CBW system highly productive. Intrusion of AS waters seems 10 to be stronger towards the upstream end $(\sim 15 \mathrm{~km})$, than had been previously reported, as a consequence of the lowering of river discharges and deepening of channels in the estuary. Time series measurements in the lower reaches of CBW indicated a low mixing zone with increased stratification, $3 \mathrm{~h}$ after the high tide (highest high tide) and high variation in vertical mixing during the spring and neap phases. The upwelled waters

$15\left(\mathrm{O}_{2} \leq 40 \mu \mathrm{M}\right)$ intruded into the estuary was found to lose more oxygen during the neap phase (suboxic $\mathrm{O}_{2} \leq 4 \mu \mathrm{M}$ ) than spring phase (hypoxic $\mathrm{O}_{2} \leq 10 \mu \mathrm{M}$ ). Increased stratification coupled with low ventilation and presence of high organic matter have resulted in an anoxic condition $\left(\mathrm{O}_{2}=0\right), 2-6 \mathrm{~km}$ away from barmouth of the estuary and leads to the formation of hydrogen sulphide. The reduction of nitrate and formation of nitrite within the oxygen deficient waters indicated strong denitrification intensity in the estuary. The expansion of oxygen deficient zone, denitrification and formation of hydrogen sulphide may lead to a destruction of biodiversity and an increase of green house gas emissions from this region.
\end{abstract}

\section{Introduction}

Globally, estuaries and coastal waters are increasingly exhibiting eutrophication due to the enrichment of nutrients caused by anthropogenic activities (Zillén et al., 2008; 
Cox et al., 2009). Increased algal production in the surface waters overlying within low oxygen environments [hypoxic $\left(\mathrm{O}_{2}<22 \mu \mathrm{M}\right)$ to suboxic $\left(\mathrm{O}_{2}<4.4 \mu \mathrm{M}\right)$ ] were transformed into anoxic $\left(\mathrm{O}_{2}=0\right)$ zones with an emission of green house gases (Naqvi et al., 2000, 2005) and leads to shifts in both pelagic and benthic organisms. Thus, coastal waters

5 are considered to be a significant source of green house gases, contributing to more than $60 \%$ of the global oceanic flux (Zhang et al., 2006; Bange et al., 1996; Bouwman et al., 1995; Nevison et al., 1995; Naqvi et al. 2005). Therefore, the contribution of estuaries to increased production of green house gases depends strongly on the intensity of oxygen depletion and denitrification caused by human-induced changes.

The Arabian Sea is one of the highly productive regions in the world, mainly due to natural processes (Naqvi et al., 2000). Enhanced biological production coupled with sinking of organic matter leads to a high oxygen demand in the intermediate depths. During summer monsoon, the existence of a strong density gradient prevents quick renewal of subsurface waters through horizontal advection (De Sousa et al., 1996). Con-

15 sequently, dissolved oxygen gets severely depleted $(<4.4 \mu \mathrm{M})$ between $150-1200 \mathrm{~m}$ depths resulting in the reduction of oxidized nitrogen species to molecular nitrogen, by denitrification (Naqvi and Qasim, 1983; Naqvi and Jayakumar, 2000a). The oxygen minimum zone (OMZ) in the AS is intense and denitrification rate is about one-third of the estimated global water column denitrification rate (Codispoti et al., 2001; Naqvi et

20 al., 2005). Hence, AS is considered to play a crucial role in regulating the atmospheric chemical composition and the earth's climate.

The biological productivity in the AS is strongly influenced by seasonal changes associated with the monsoon. During the summer monsoon period, the wind driven upwelling along the southwest coast of India is vigorous when compared to that of

25 Somalia, Yemen and Oman (Naqvi et al., 2006). The upwelled water is located just off the shelf break (Shetye et al., 1990), where the coastal circulation and tides has a dominant role in advecting these waters into the estuaries. The estuaries of the northwest coast (Mumbai) have a mean tidal height $(\sim 3 \mathrm{~m})$ higher than (Srinivas et al., $2006)$ that of southwest coast $(\sim 1 \mathrm{~m})$. The low tidal amplitudes and increasing number

1753

of oscillations in the SW coast may lead to small inter-tidal expanses, which reduce flushing (Qasim, 2003).

The CBW is one of the largest estuarine systems along the west coast of India (Fig. 1), running parallel to the SW coast with a relatively lower $(\sim 1 \mathrm{~m})$ tidal amplitude 5 (Srinivas et al., 2003). The system is influenced by monsoonal rains (annual average rain fall of $3200 \mathrm{~mm}$ ), contributing to $75 \%$ of the annual rainfall during the summer monsoon season (June-September). River discharge (from 7 rivers) brings high nutrients to make CBW highly productive (Madhu et al., 2007). Increased anthropogenic activities of this region generates $104 \times 10^{3} \mathrm{~m}^{3}$ of industrial and $260 \mathrm{~m}^{3}$ of domestic wastes

10 per day, which are being released directly into the estuary without any treatment (Balachandran et al., 2005; Martin et al., 2008). The Cochin backwaters are known for their rich bio-resources, but in the pristine conditions have suffered severe depletion due to human intervention (Menon et al., 2000; Martin et al., 2008).

Major interventions in the CBW started from 1920's for different developmental ac15 tivities such as construction of harbor, industrial areas, expansion of Wellington Island and intensive reclamations for human settlement. Due to these activities in the beginning of the $19^{\text {th }}$ century, the total area of CBW has shrunken from $365 \mathrm{~km}^{2}$ to $256 \mathrm{~km}^{2}$ (Gopalan et al., 1983; Balachandran et al., 2005). Apart from this, a removal of 2.5 million cubic yards of silt associated with periodic dredging every year to maintain ship-

20 ping channel (Gopalan et al., 1983) will drastically influence channel cross section and depth (Joseph and Kurup, 1989). This could lead to an increase in tidal storage, sluggish water movements and decreased flushing rates, which may expedite stratification and sedimentation process (Joseph et al., 2009). In this paper, the influence of coastal hydrography on the adjacent CBW has examined during summer monsoon period to 25 identify the causative factors responsible for the development of anoxia and denitrification process. 


\section{Materials and methods}

\subsection{Study area}

The Arabian Sea experiences biannually reversing winds and associated circulations during the summer and winter monsoons. Western India has a divergent and passive 5 continental margin (Ramalingeswara Rao and Veerayya, 2000) from Cape Comorin $\left(8^{\circ} \mathrm{N}\right)$ to Kutch $\left(22^{\circ} \mathrm{N}\right)$. Many small rivers like the Mandovi and Zuari in Goa, the Kalinadi in north Kanara and the Netravati in south Kanara flow across the coastal plain and opens into the AS. CBW (also known as Vembanad lake) and the Ashtamudi lake are the two major estuaries debouching freshwater into the Arabian Sea (Purnachan10 dra Rao et al., 1983) from the south.

The CBW (Lat. $9^{\circ} 30^{\prime}-10^{\circ} 10^{\prime} \mathrm{N}$ and Lon. $76^{\circ} 15^{\prime}-76^{\circ} 25^{\prime} \mathrm{E}$ ) constitutes a complex estuarine system (Fig. 1), characterized by an ox-bow shape, running parallel to Arabian Sea (Soman, 1997). Due to its peculiar topography, the circulation patterns in the northern and southern arms of the CBW are found to be different (Ramamirtham

15 and Muthusamy, 1986). Hence, the high freshwater flow during summer monsoon supresses the tidal charateristics and increases stratification in the lower estuary (Qasim and Gopinathan, 1969). CBW is connected to the AS through two inlets, one at Cochin and other at Azhikode, the former being wider $(450 \mathrm{~m})$ than the latter $(250 \mathrm{~m})$. The CBW is generally wide $(0.8-1.5 \mathrm{~km})$ and deep $(4-13 \mathrm{~m})$ towards south but becomes narrow $(0.05-0.5 \mathrm{~km})$ and shallow $(0.5-3.0 \mathrm{~m})$ towards north. It is a bar-built microtidal estuary (with a tidal height of $\sim 0.9 \mathrm{~m}$ at spring tide and $\sim 0.5 \mathrm{~m}$ at neap tide), receiving large volume of fresh water runoff $\left(22 \times 10^{9} \mathrm{~m}^{3}\right.$ year $\left.^{-1}\right)$ from seven rivers (Fig. 2a and b) mainly during the summer monsoon (July). Monthly river discharge data (Fig. 2a) showed a high seasonality, $60-70 \%$ of the total discharge occurring during the south25 west monsoon (June-September). The yearly wise river discharge (mean) data (obtained from Central water commission, India) from 7 major rivers indicates a decrease in discharge during the last few decades especially after 1995. The drastic decrease in discharge (Fig. 2b) was noticed from the southern rivers than the north. The major 1755

decrease was found in the river Periyar and Muvattupuzha $\left(450 \mathrm{Mm}^{3}\right.$ to $50 \mathrm{Mm}^{3}$ and $250 \mathrm{Mm}^{3}$ to $75 \mathrm{Mm}^{3}$ ). This could be due to the construction of dams and check dams (10 nos) in the rivers (P. Shaiju, personnel communication, 2008).

\subsection{Sampling and analysis}

5 Hydrographic observations were carried out onboard FORV Sagar Sampada (SS 227 and SS 229) from the AS along $10^{\circ} \mathrm{N}$ during summer monsoon July 2004. Oceanic water samples were collected up to $200 \mathrm{~m}$ depth while near shore samples were collected depending on the depth at each station. Water samples were generally collected from standard depths $(0,10,20,30,50,75,100,150,200 \mathrm{~m})$ using a $1.7 \mathrm{~L}$ Niskin sampler

10 fitted to a Sea Bird (Model SBE-911 ${ }^{\text {plus }}$ ) Conductivity-Temperature-Depth (CTD) (accuracy of conductivity $0.0003 \mathrm{~S} / \mathrm{m}$, temperature $0.001^{\circ} \mathrm{C}$ and pressure $0.015 \%$ ) rosette system. Salinity and temperature were measured at every $1 \mathrm{~m}$ depth interval and recorded. CTD - derived salinities were corrected against water samples collected from respective depth and measured using Autosal Guildline 8400 after calibration 15 with standard seawater (IAPSO standard seawater). Dissolved oxygen (DO) was estimated by Winkler's titrimetric method (Grasshoff et al., 1983). Dissolved inorganic nutrients such as nitrite- $\mathrm{N}\left(\mathrm{NO}_{2}^{-}\right)$, nitrate- $\mathrm{N}\left(\mathrm{NO}_{3}^{-}\right)$, phosphate- $\mathrm{P}\left(\mathrm{PO}_{4}^{3-}\right)$ and silicate$\mathrm{Si}\left(\mathrm{SiO}_{4}^{4-}\right)$ were estimated following standard colorimetric techniques (Grasshoff et al., 1983), using a 4-channel Skalar Segmented Flow analyzer (Model SA-1050) onboard.

20 In-situ primary productivity (PP) and chlorophyll a measurements were carried out one from offshore and one from inshore station at seven standard depths (Surface, 10, 20, 50, 75, 100 and $120 \mathrm{~m}$ ). Before PP incubation, seawater samples collected (before sunrise) from seven depths were sieved through $200 \mu \mathrm{m}$ mesh net to remove mesozooplankton. Sample from each depth was transferred into five $300 \mathrm{ml}$ ( 3 light and 2 dark)

25 polycarbonate bottles (Nalgene - Germany). One ampoule of $\mathrm{NaH}^{14} \mathrm{CO}_{3}$ (BRIT, Mumbai specific activity $5 \mu \mathrm{Ci}$ ) was added to each bottle and lowered to the respective sampling depth with the help of a mooring system and incubated from sunrise to half 
an hour after sunset. The samples were then retrieved and passed through GF/F filters, exposed to $\mathrm{HCl}$ fumes to remove inorganic carbon and transferred to scintillation vials. Later in the laboratory, $5 \mathrm{ml}$ of scintillation cocktail-T was added to each vial, kept overnight and the radioactivity was measured using liquid scintillation counter (Wallac

51409 DSA Perkin Elmer, USA). The primary production rate was calculated according to the equation given in the JGOFS protocol (UNESCO, 1994). For chlorophyll $a$, one Liter of water sample from each depth was filtered through whatmann GF/F filter and measured according to Strickland and Parsons (1972) using spectrophotometer (Shimadzu 1650 PC).

10 In the CBW, Synchronous CTD profiling ( $1 \mathrm{~h})$ and water quality measurements $(3 \mathrm{~h})$ were carried out at Fort Kochi (lower estuary) over a tidal cycle $(27 \mathrm{~h})$ during one spring (16 July 2007) and one neap (24 July 2007) phase. Water samples were collected from surface, mid depth and $1 \mathrm{~m}$ above from the bottom and analyzed for nutrients within $3 \mathrm{~h}$ in the shore laboratory using (Shimadzu $1650 \mathrm{PC}$ ) spectrophotometer following 15 standard procedure (Grasshoff et al., 1983). These samples were also analyzed for DO, chlorophyll $a$ and PP by same methods mentioned above.

Salinity intrusion study (CTD - SBE $9^{11}$ plus) was carried out in the CBW by measuring at every $5 \mathrm{~km}$ intervals from north to south using a speed boat $(40 \mathrm{~km} / \mathrm{h})$ during the spring and neap tides. Apart from this, water quality measurements $\left(\mathrm{DO}, \mathrm{NO}_{3}\right.$, $20 \mathrm{NO}_{2}, \mathrm{H}_{2} \mathrm{~S}$ ) were carried out for samples collected at $1 \mathrm{~m}$ above the bottom (to avoid the sediment interferences) using another boat from the barmouth towards southern estuary $\left(20 \mathrm{~km}\right.$ towards upstream) in consistence with peak high tide. DO and $\mathrm{H}_{2} \mathrm{~S}$ were fixed onboard and analyzed in the laboratory according to the method of Grasshoff et al. (1983). In our earlier studies, entire estuary (56 stations) was sampled to study 25 dissolved organic carbon (DOC), particulate organic carbon (POC) and particulate nitrogen (PN) during summer monsoon (September 2005). Surface water samples were collected using a Niskin sampler (Hydrobios $5 \mathrm{~L}$ ). DOC, POC and PN samples were transferred into glass bottles (pre-combusted at $450^{\circ} \mathrm{C}$ for $4 \mathrm{~h}$ ) and ice preserved in dark during the transport to the laboratory. In the laboratory, a known volume of sam-

1757

ple $(100 \mathrm{ml})$ was filtered through $25 \mathrm{~mm}$ GF/F filters (Whatman, Maidstone, UK) precombusted at $450^{\circ} \mathrm{C}$ for $4 \mathrm{~h}$. Filtrates were acidified to $\mathrm{pH} 3.5-4.0$ using $1 \%$ phosphoric acid and stored in $10 \mathrm{ml}$ air-tight glass tubes (pre-combusted) at $10^{\circ} \mathrm{C}$ until analysis. DOC was measured following high temperature catalytic oxidation using a TOC ana5 lyzer (Shimadzu TOC-VCPH). The accuracy of DOC measurements was checked once in every five samples with a Certified Reference Material supplied by D. Hansell, University of Miami, USA (Batch $5 \mathrm{FS}$ ) and with internal standards prepared using potassium hydrogen phthalate $\left(1\right.$ and $5 \mathrm{mg} \mathrm{L}^{-1}$ ), the maximum deviation was $1 \%$. The filtered $25 \mathrm{~mm}$ GF/F filters kept in the deep-freezer was used for POC and PN analysis. Later,

10 they were analyzed by elemental analyzer (Thermo Finningan, Flash EA1112) using L-Cystine as standard. The precision of the analysis was checked against standard reference material (NIST 1941B) and was found to be $0.4 \pm 0.1 \%$ for $\mathrm{C}$ and $0.5 \pm 0.2 \%$ for $\mathrm{N}$.

\section{Results}

\section{$15 \quad 3.1$ Hydrography}

\subsubsection{Offshore to coastal waters of the Cochin}

Western continental shelf of India is experiencing coastal upwelling, characterized by cool $\left(\mathrm{SST}<26^{\circ} \mathrm{C}\right)$, high saline $(>35.0)$, low oxygenated $(<170 \mu \mathrm{M})$ and nutrient rich $\left(\mathrm{NO}_{3}>2 \mu \mathrm{M}, \mathrm{PO}_{4}>0.8 \mu \mathrm{M}, \mathrm{SiO}_{4}>5 \mu \mathrm{M}\right)$ waters in the surface layers (Fig. 3). Vertical 20 section of temperature clearly shows an upsloping of isotherms from deeper waters $(>80 \mathrm{~m})$ of oceanic regions to the subsurface waters $(15 \mathrm{~m})$ of coastal regions. Salinity and density profiles also showed the same trend with high saline (35) and denser $\left(23.5 \mathrm{~kg} / \mathrm{m}^{3}\right)$ waters upsloping towards the coast. The subsurface coastal waters were relatively deficient in oxygen $(<40 \mu \mathrm{M})$ and rich in nutrients $\left(\mathrm{NO}_{3}>4 \mu \mathrm{M}, \mathrm{PO}_{4}>1 \mu \mathrm{M}\right.$ 25 and $\mathrm{SiO}_{4}>5 \mu \mathrm{M}$ ) compared to the oceanic stations. 


\subsubsection{Estuary}

Spring and neap phases during the monsoon (July) (Fig. 4) showed a remarkable variation in the water level and hydrography at the lower estuary. Maximum water level variation (Fig. 4a) was recorded during the spring phase $(90 \mathrm{~cm})$ than neap phase

$5(65 \mathrm{~cm})$. During neap tide, surface waters were low saline and warmer $\left(\sim 1\right.$ and $27^{\circ} \mathrm{C}$, respectively) compared to spring tide $\left(\sim 5\right.$ and $26^{\circ} \mathrm{C}$, respectively) whereas the intermediate waters during neap tide $\left(3-30\right.$ and $23.5-27^{\circ} \mathrm{C}$, respectively) exhibited low mixing compared to spring phase $\left(5-25\right.$ and $24.5-25.5^{\circ} \mathrm{C}$, respectively). The bottom waters, remained cooler $\left(23-23.5^{\circ} \mathrm{C}\right)$ and high saline $(32-34)$ during the high tide of both spring and neap phases (Fig. $4 \mathrm{~b}$ and c). Weakly stable intermediate layer was noticed during the spring phase (50 cycles/h) as compared to the neap phase (100 cycles $/ \mathrm{h}$ ).

In the neap and spring phases, dissolved oxygen remained saturated (180-200 $\mu \mathrm{M})$ in the surface waters during low tide, while inorganic nutrients $\left(\mathrm{NO}_{3}>8 \mu \mathrm{M}, \mathrm{PO}_{4}>1 \mu \mathrm{M}\right.$ and $\mathrm{SiO}_{4}>25 \mu \mathrm{M}$ ) exhibited higher concentrations at all the time intervals (Fig. 4a and

$15 \mathrm{c}$ ). But there was a progressive depletion of oxygen (hypoxic to suboxic) from the intermediate to deeper layers $(20-10 \mu \mathrm{M})$ during the high tide and its amplitude was found to be high during the neap phase $(20-4 \mu \mathrm{M})$. Along with the oxygen depletion, a reduction of nitrate $(25-20 \mu \mathrm{M})$ with a high nitrite concentration $(2 \mu \mathrm{M})$ were noticed $3 \mathrm{~h}$ after the high tide.

\subsection{Intrusion of upwelled water to the estuary}

The surface to intermediate waters $(0-4 \mathrm{~m})$ was found to be low saline $(0-16)$ due to the mixing of seaward flowing river influx and intruding upwelled waters (Fig. $5 a$ and b) during the spring and neap phases. In the spring phase, high saline waters were found in the surface layers indicating strong vertical mixing (weak stratification) compared 25 to the neap phase (strong stratification). During the spring phase high tide, intrusion of saline waters (2-34) was observed from the barmouth to southern estuary up to $30 \mathrm{~km}$, while towards northern estuary it was less than $10 \mathrm{~km}$. The high saline water

1759

mass (25-34) in the bottom layers was traced up to $15 \mathrm{~km}$ during the spring phase and up to $8 \mathrm{~km}$ during neap phase.

Dissolved oxygen, nitrate and nitrite (Fig. 5c) followed a reverse pattern with the intrusion of upwelled waters. The severe oxygen depletion $\left(\mathrm{O}_{2}=0\right)$ in the stations 5 away $(2-6 \mathrm{~km})$ from barmouth coincided with low nitrate, high nitrite and high hydrogen sulphide concentration during the neap phase. The denitrification intensity was low (nitrite $1.8 \mu \mathrm{M}$ ) during the spring phase. Towards the upper reaches of the estuary $(15-18 \mathrm{~km})$ an increase in dissolved oxygen $(60-110 \mu \mathrm{M})$, high nitrate $(20-25 \mu \mathrm{M})$ and low nitrite concentration $(0.1-0.3 \mu \mathrm{M})$ was observed.

10 3.3 Chlorophyll a (Chl a) and primary productivity (PP)

Chlorophyll a (surface and column) and PP (surface and column) showed a substantial increase from offshore towards the estuary (Fig. 6). Surface Chl-a and PP were very high $\left(23.5 \mathrm{mg} / \mathrm{m}^{3}\right.$ and $2847 \mathrm{mgC} / \mathrm{m}^{3} /$ day $)$ in the estuary compared to near shore coastal $\left(11.21 \mathrm{mg} / \mathrm{m}^{3}\right.$ and $160.55 \mathrm{mgC} / \mathrm{m}^{3} /$ day $)$, near shore open $\left(1.29 \mathrm{mg} / \mathrm{m}^{3}\right.$ 15 and $90.19 \mathrm{mgC} / \mathrm{m}^{3} /$ day) and offshore $\left(0.11 \mathrm{mg} / \mathrm{m}^{3}\right.$ and $2.08 \mathrm{mgC} / \mathrm{m}^{3} /$ day) regions. Column Chl-a and PP were also high $\left(164.5 \mathrm{mg} / \mathrm{m}^{2}\right.$ and $19411 \mathrm{mgC} / \mathrm{m}^{2} /$ day) in the estuary compared to near shore coastal $\left(132.08 \mathrm{mg} / \mathrm{m}^{2}\right.$ and $2135.52 \mathrm{mgC} / \mathrm{m}^{2} /$ day), near shore open $\left(33.55 \mathrm{mg} / \mathrm{m}^{2}\right.$ and $1738.93 \mathrm{mgC} / \mathrm{m}^{2} /$ day $)$ and offshore $\left(31.4 \mathrm{mg} / \mathrm{m}^{2}\right.$ and $297.85 \mathrm{mgC} / \mathrm{m}^{2} /$ day) stations.

\section{3.4 Distribution of organic fractions in the estuary}

Organic matter enrichment in the CBW is attributed to the indiscriminate release of industrial, urban, agricultural and aquaculture wastes into the estuary (Qasim, 2003). High concentrations of DOC, POC and PN were found in the entire estuary during the study period (Fig. 7$)$. DOC showed a significant spatial variability $(20 \mu \mathrm{M}-480 \mu \mathrm{M})$ in the southern and northern regions with a decreasing trend towards the lower estuary $(190.9 \pm 96.2 \mu \mathrm{M})$. POC and $\mathrm{PN}$ also exhibited the same trend, with values varying 
between $20-320 \mu \mathrm{M}$ and $2-40 \mu \mathrm{M}$, respectively. DOC, POC and PN are found to be co-existent with low values in the lower reaches of the estuary.

\section{Discussion}

\subsection{Influence of summer monsoon hydrography of AS on CBW}

5 The wind driven upwelling brings cool, oxygen deficient and nutrient rich waters towards the SW coast of India. Strong coupling between physico-chemical conditions during upwelling makes the coastal waters highly fertile (Habeebrehman et al., 2008) and enhances primary production several fold higher than the offshore waters (Ryther, 1963). West Indian Coastal Current (WICC) brings in Arabian Sea High Saline Wa-

10 ters (ASHSW) towards south and spread along the southwest coast of India during upwelling, while intense river runoff reduces the surface salinity considerably (Shetye et al., 1990), as was evident in the present study.

High river discharge during the summer monsoon lowers the surface salinity to almost zero in the entire CBW (Qasim, 2003). A tongue of fresh water juts out from

15 the estuary during this season, imparting fluctuations in surface salinity in the adjacent coastal waters of the AS (Darbyshire, 1967). Concurrent with this fresh water discharge, an intrusion of low saline $(>28)$ waters of $\sim 3 \mathrm{~km}$ was observed from the AS to CBW in the bottom layers during high tide (Ramamirtham and Jayaraman, 1963). The extent of this intrusion is found to be increased to $\sim 6 \mathrm{~km}$ during the high tide of a 20 spring phase (Udaya Varma et al., 1981). During the present study the cold, high saline AS upwelled waters was found to intrude up to $15 \mathrm{~km}$ upstream towards the estuary (Fig. $5 a$ and b), which is by far, the longest extent reported for the estuary and this could probably be due to the decreased river discharge and increased channel depth of the estuary.

25 Increased nutrient inputs to the CBW is not only from the rivers but also contributed by increased industrial and domestic activities (Jyothibabu et al., 2006). The initial

1761

monsoon rain, after the dry summer period (January to May) washes the adjacent land area and drain nutrient enriched waters to CBW, making the system highly productive (Qasim, 2003; Madhu et al, 2007). The results of the present study also corroborates this because the primary productivity (Fig. 6) recorded in the CBW was much higher

5 than that observed in the inshore and offshore waters. Despite the high productivity, the transfer coefficient from primary to secondary level in the CBW is only $7 \%$ and the excess organic matter may be transported to the coastal waters or sink within the estuary (Madhupradhap et al., 1980; Jyothibabu et al., 2006).

In the CBW, the organic matter loading is both from autochthonous and al10 lochthonous sources (Devi et al., 1983). The high POC, DOC and PN in the central estuary (Fig. 7) indicate that a significant portion of organic matter is derived from domestic inputs from the adjacent city. Together with this, the wastes from aquaculture fields $\left(62 \mathrm{~km}^{2}\right)$, agricultural fields $\left(80 \mathrm{~km}^{2}\right)$ and retting yards in the south estuary worsens the organic pollution (Thomson, 2002; Babu et al., 2006). Raymond and

15 Bauer (2001) reported a negligible degradation of organic matter in rivers but is largely degraded during estuarine mixing and the decreased value of DOC, POC and PN observed in the lower estuary may be due to the increased degradation of organic matter. The impoverishment of organic matter along with high turbidity in the lower estuary triggers bacterial respiration rates. It is also noted that organic matters from the rivers

20 are labile and thus would contribute to an increase in oxygen consumption when entrained in stagnated estuarine waters (Rabouille, et al., 2008). Thus, autochthonous and allochthonous inputs coupled with high bacterial respiration will create a high $\mathrm{O}_{2}$ demand in the bottom layers (Karim, et al., 2002).

\subsection{Influence of hydrography on the severe oxygen depletion and denitrification in the CBW}

The geomorphological changes and lowering of river discharge have severely influenced the hydrography of AS and CBW. During the summer monsoon period, AS sub surface water, which is cold, high saline and deficient in dissolved oxygen, juts towards 
the shelf (Naqvi et al., 2006). This upwelled water mass (cold-26 ${ }^{\circ} \mathrm{C}$, high saline-34, low DO 20-40 $\mu \mathrm{M}$ ) intrudes into the CBW (Fig. 4b and $\mathrm{c}$ and Fig. 5a-c) during high tide (15km during spring and $8 \mathrm{~km}$ during neap). During spring tide, high tidal energy induces high mixing and low stratification but at neap tide, low tidal energy diminishes

5 mixing and increase stratification as evident from the present observation (Fig. $4 \mathrm{~b}$ and c). Increased residence time of water body was noticed during peak high tide in the lower estuary due to the sluggish movement of water through a small tidal inlet (Joseph et al., 2009). Increased residence time of bottom waters in the estuaries have a direct effect on the duration of oxygen consumption via organic matter decomposition 10 and thus severely depletes dissolved oxygen values to hypoxic levels (Rabouille et al., 2008).

The intrusion of low oxygenated (hypoxic) waters from the AS into CBW through its bottom layers is environmentally critical due to the presence of high organic matter in the water column. Dissolved oxygen was generally saturated in CBW at any stage of

15 tide and an inverse relationship with salinity was reported in the earlier studies (Qasim and Gopinathan, 1969; Sankaranarayanan and Qasim, 1969). Depletion of oxygen (up to $0.25 \mathrm{ml} / \mathrm{l}$ ) due to the oxidation of high organic matter (macrophyte weed matter) in the upper reaches of CBW has also been reported (Unnithan et al., 1975; Sheeba, 2000). In our studies, it was evident that depletion of dissolved oxygen was due to the 20 upwelled propagation of high saline water mass and its increased residence time in the lower estuary. Furthermore, intruding amplitude of AS oxygen deficient waters (20$40 \mu \mathrm{M})$ into the estuary has increased when compared with an earlier study $(148 \mu \mathrm{M}-$ Vijayalakshmi and Venugopalan, 1973). So far, this condition has not been established in the tropical estuarine conditions.

25 Oxygen in the CBW was found to be severely depleted and extended to a larger area from the lower to upper estuary $(2-6 \mathrm{~km})$. This severe oxygen depletion (hypoxic to anoxic) was well correlated with the stratification and was found to be stronger $3 \mathrm{~h}$ after the high tide of neap phase compared to spring phase. During the peak high tide period null zones develop within the southern and northern part of CBW due to

1763

increased stratification (Balachandran et al., 2005, 2008), which leads to an increased settling of organic matter (autochthonous and allochthonous) towards the bottom layers. Low vertical mixing coupled with increased stratification and poor ventilation leads to sustenance of oxygen already contained in the bottom waters. These processes are 5 clearly reflecting in the oxygen values during the spring and neap phases. High biological oxygen demand $\left(\mathrm{BOD}_{5}-(7-16 \mathrm{mg} / \mathrm{l})\right.$ - unpublished data) and increased bacterial respiration rate (Thottathil et al., 2008; Guptha et al., 2009) could lead to the quick removal of oxygen (within $3 \mathrm{~h}$ ) in the estuary. High suspended particulate matter (80$120 \mathrm{mg} / \mathrm{l}$ ) and turbidity (transparency - av. $0.5 \mathrm{~m}$ ) in the lower reaches of CBW (Madhu

10 et al., 2007) also lower the dissolved oxygen content by inhibiting photosynthetic oxygen production. Very low DO has also been reported in highly polluted upper reaches of Scheldt estuary (Frankignoulle et al., 1996, 1998; Abril and Frankignoulle, 2001), where depletion was attributed to the high respiration of organic matter and increased residence time of water within the estuary (Frankignoulle et al., 1996; Hellings et al.,

15 2001). The important biogeochemical process during severe oxygen depletion is the switch over of bacteria to nitrate for the oxidation of organic matter (Morrison et al., 1999).

The hypoxic zone $\left(\mathrm{O}_{2}<22 \mu \mathrm{M}\right)$ is an important biological boundary where oxygen becomes a limiting factor for respiration and nitrate reduction (Devol, 1978). The anoxic

20 zone was extending from 2 to $6 \mathrm{~km}$ from the barmouth towards south estuary. This was coupled with the formation of a denitrification layer enriched with nitrite and hydrogen sulphide which was possibly due to the increased stratification and high bacterial respiration rates. The lowering of nitrate concentration in the oxygen deficient zone (ODZ) was due to denitrification as was evident from the high nitrite concentration $(2 \mu \mathrm{M})$.

25 Hence, the high nitrite concentration in the bottom layers appears to be linked with the increased oxygen demand and strong heterotrophic behavior (Thottathil et al., 2008). The hydrogen sulphide noted $(0-12 \mathrm{~km})$ in the bottom layers is possibly due to sulphate reduction. Therefore we conclude that severe oxygen depletion and formation of greenhouse gases over CBW is due to the presence of high organic matter degradation 
and increased stratification of upwelled water.

The nitrite tongue in the surface layer of coastal waters (Fig. 3) is possibly due to the ammonia oxidation by nitrifying bacteria (Olson, 1981). This nitrification coupled with denitrification may leads to nitrogen emission to the atmosphere (Herbert, 1999).

5 Therefore, the moderate nitrification (Miranda et al., 2007) coupled with denitrification in CBW can increase emission of greenhouse gases. The anthropogenic loading into flow-restricted water bodies induces severe oxygen demand to different degrees in many European estuaries, such as Forth, Scheldt, Seine and Lorire (Balls et al., 1996; Frankignoulle et al., 1996; Abril and Frankignoulle, 2001; Garnier et al., 2001; Hellings 10 et al., 2001; Abril et al., 2003). Hypoxic cases have been found in bottom waters of either salt wedge estuaries or on coastal shelves during stratified conditions (Kemp et al., 1992; Ritter and Montagna, 1999). Thus oxygen becomes one of the most limiting factors for many organisms at higher trophic levels (benthic and pelagic), and this may alter the ecosystem balance of the estuary. Increased oxygen demand in the stratified

15 waters enhances denitrification, which is significant for CBW because of its proximity to the world's largest denitrifying zone.

\section{Conclusions}

The formation of anoxia in the bottom waters of lower CBW is a first time report in the estuaries along the West coast of India. The decreased river flow and increased

20 deepening of channels has probably reduced the natural flow and increased intrusion of upwelled coastal waters. Upwelled waters from the AS to the CBW leads to further oxygen depletion due to weak flushing along with high organic input from anthropogenic loadings. This anoxia ultimately leads to denitrification and the formation of greenhouse gases like hydrogen sulphide and nitrous oxide in the bottom waters. Oxygen

25 becomes a limiting factor for many organisms at higher levels, and this may be a reason for their exclusion from this zone. Estuaries represent one of the most sensitive and ecologically important habitats on earth and serve as breeding grounds for many en-

1765

demic species. Countries along the Indian Ocean account for approximately a quarter of the world's human population, which in conjunction with the rapid economic growth makes the region's coastal environments experiencing $\mathrm{O}_{2}$-deficiency and formation of toxic gases highly vulnerable to mankind. The region is expected to undergo an explo-

5 sive development (with proposed vallarpadam port development project estimated at US $\$ 1000$ million) in the next 5 years. In view of the alarming rate at which the region is growing ( 0.6 million in 1975 to 3 million in 2002 and an expected 5 million population by 2025), there should be proper environmental conservation plans to minimize the excessive pollution, keeping pace with developmental impacts that are inevitable.

10 Acknowledgements. The authors are thankful to the Directors of NIO, ICMAM-PD, CMLRE, CUSAT and Scientist-in-Charge, NIO-RC, Cochin for the encouragement rented towards the work. This study forms a part of project "Ecosystem Modeling of Cochin backwaters" and "Environment and productivity patterns of the Indian EEZ" funded by Ministry of Earth Sciences (this is an NIO Contribution).

\section{References}

Abril, G. and Frankignoulle, M.: Nitrogen-alkalinity interactions in the highly polluted Scheldt basin (Belgium), Water. Res., 35, 844-850, 2001.

Abril, G., Etcheber, H., Delille, B., Frankignoulle, M., and Borges, A. V.: Carbonate dissolution in the turbid and eutrophic Loire estuary, Mar. Ecol. Prog. Ser., 259, 129-138, 2003.

20 Babu, M. T., Kesava Das, V., and Vethamony, P.: BOD-DO modeling and water quality analysis of a waste water outfall off Kochi, west coast of India, Environ. Int., 32, 165-173, 2006.

Balachandran, K. K., Lalu Raj, C. M., Nair, M., Joseph, T., Sheeba, P., and Venugopal, P.: Heavy metal accumulation in a flow restricted, tropical estuary, Estuar. Coast. Shelf. Sci., 65 , 361-370, 2005.

25 Balachandran, K. K., Reddy, G. S., Revichandran, C., Srinivas, K., Vijayan, P. R., and Thottam, T. J.: Modelling of tidal hydrodynamics for a tropical ecosystem with implications for pollutant dispersion (Cochin estuary, southwest India), Ocean. Dyn., 58, 259-273, 2008.

Balls, P. W., Brockie, N., Dobson, J., and Johnston, W.: Dissolved oxygen and nitrification in the 
upper forth estuary during summer (1982-1992): Patterns and trends, Estuar. Coast. Shelf. Sci., 42, 117-134, 1996.

Bange, H. W., Rapsomanikis, S., and Andreae, M. O.: Nitrous oxide in coastal waters, Global. Biogeochem. Cy., 10, 197-207, 1996.

5 Bouwman, A. F., Van der Hoek, K. W., and Olivier, J. G. J.: Uncertainties in the global source distribution of nitrous oxide, J. Geophys. Res., 100, 2785-2800, 1995.

Codispoti, L. A., Brandes, J. A., Christensen, J. P., Devol, A. H., Naqvi, S. W. A., Paerl, H. W., and Yoshinari, T.: The oceanic fixed nitrogen and nitrous oxide budgets: Moving targets as we enter the anthropocene?, Sci. Mar., 65, 85-105, 2001.

10 Cox, T. J. S., Maris, T., Soetaert, K., Conley, D. J., Van Damme, S., Meire, P., Middelburg, J. J., Vos, M., and Struyf, E.: A macro-tidal freshwater ecosystem recovering from hypereutrophication: the Schelde case study, Biogeosciences, 6, 2935-2948, 2009, http://www.biogeosciences.net/6/2935/2009/.

Darbyshire, M.: The surface waters off the coast of Kerala, south-west India, Deep-Sea. Res. I., 14, 295-320, 1967.

DeSousa, S. N., DileepKumar, M., Sardessai, S., Sarma, V., and Shirodkar, P. V.: Seasonal variability in oxygen and nutrients in the central and eastern Arabian sea, Curr. Sci. India., 71, 847-851, 1996.

Devi, K. S., Venugopal, P., Remani, K. N., Zacharias, D., and Unnithan, R. V.: Nutrients in some estuaries of Kerala, Mahasagar, 16, 161-173, 1983.

Devol, A.: Bacterial oxygen uptake kinetics as related to biological processes in oxygen deficient zones of the oceans, Deep-Sea. Res. II., 25, 137-146, 1978.

Frankignoulle, M., Abril, G., Borges, A., Bourge, I., Canon, C., Delille, B., Libert, E., and Théate, J. M.: Carbon dioxide emission from European estuaries, Science, 282, 434-436, 1998.

25 Frankignoulle, M., Bourge, I., and Wollast, R.: Atmospheric $\mathrm{CO}_{2}$ fluxes in a highly polluted estuary (The Scheldt), Limnol. Oceanogr., 41, 365-369, 1996.

Garnier, J., Servais, P., Billen, G., Akopian, M., and Brion, N.: The oxygen budget in the seine estuary: Balance between photosynthesis and degradation of organic matter, Estuaries, 24, 964-977, 2001.

30 Gopalan, U. K., Vengayil, D. T., Udaya Varma, V. P., and Krishnankutty, M.: The shrinking backwaters of Kerala, J. Mar. Biol. Ass. India, 25, 131-141, 1983.

Grasshoff, K., Ehrhardt, M., and Kremling, K. (eds.): Methods of Seawater Analysis, Verlag Chemie, Weinheim, 419 pp., 1983.

Gupta, G. V. M., Thottathil, S. D., Balachandran, K. K. Madhu, N. V., Madeswaran, P., and Nair, S.: $\mathrm{CO}_{2}$ Supersaturation and Net Heterotrophy in a Tropical Estuary (Cochin, India): Influence of Anthropogenic Effect Carbon Dynamics in Tropical Estuary, Ecosystems, 12, 1145-1157, 2009.

5 Habeebrehman, H., Prabhakaran, M. P., Jacob, J., Sabu, P., Jayalakshmi, K. J., Achuthankutty, C. T., and Revichandran, C.: Variability in biological responses influenced by upwelling events in the eastern Arabian sea, J. Marine. Syst., 74, 545-560, 2008.

Hellings, L., Dehairs, F., Van Damme, S., and Baeyens, W.: Dissolved inorganic carbon in a highly polluted estuary (The Scheldt), Limnol. Oceanogr., 46, 1406-1414, 2001.

10 Herbert, R. A.: Nitrogen cycling in coastal marine ecosystems, FEMS Microbiol. Rev., 23, 563$590,1999$.

Joseph, A., Mehra, P., Prabhudesai, R. G., Sivadas, T. K., Balachandran, K. K., Vijaykumar, K., Revichandran, C., Agarvadekar, Y., Francis, R., and Martin, G. D.: Observed thermohaline structure and cooling of Kochi backwaters and adjoining southeastern Arabian sea, Curr. Sci. India., 96, 364-375, 2009.

Joseph, J. and Kurup, P. G.: Volume transport and estuarine features at Cochin inlet, Mahasagar, 22, 165-172, 1989.

Jyothibabu, R., Madhu, N. V., Jayalakshmi, K. V., Balachandran, K. K., Shiyas, C. A., Martin, G. D., and Nair, K. K. C.: Impact of freshwater influx on microzooplankton mediated food web

20 in a tropical estuary (Cochin backwaters - India), Estuar. Coast. Shelf. Sci., 69, 505-518, 2006.

Karim, M. R., Sekine, M., and Ukita, M.: Simulation of eutrophication and associated occurrence of hypoxic and anoxic condition in a coastal bay in Japan, Mar. Pollut. Bull., 45, 280285, 2002.

25 Kemp, W. M., Sampou, P. A., Garber, J., Tuttle, J., and Boynton, W. R.: Seasonal depletion of oxygen from bottom waters of Chesapeake bay: Roles of benthic and planktonic respiration and physical exchange processes, Mar. Ecol.-Prog. Ser., 85, 137-152, 1992.

Madhu, N. V., Jyothibabu, R., Balachandran, K. K., Honey, U. K., Martin, G. D., Vijay, J. G., Shiyas, C. A., Gupta, G. V. M., and Achuthankutty, C. T.: Monsoonal impact on plank-

30 tonic standing stock and abundance in a tropical estuary (Cochin backwaters-India), Estuar. Coast. Shelf. Sci., 73, 54-64, 2007.

Madhupratap, M.: Ecological releationship of coexisting copepod species from Cochin backwaters, Mahasagar, 13, 45-52, 1980. 
Martin, G. D., Vijay, J. G., Laluraj, C. M., Madhu, N. V., Joseph, T., Nair, M., Gupta, G. V. M., and Balachandran, K. K.: Fresh water influence on nutrient stoichiometry in a tropical estuary, southwest coast of India, Appl. Ecol. Environ. Res., 6, 57-64, 2008.

Menon, N. N., Balchand, A. N., and Menon, N. R.: Hydrobiology of the Cochin backwater system a review, Hydrobiologia, 430, 149-183, 2000.

Miranda, J., Balachandran, K. K., Ramesh, R., and Wafar, M.: Nitrification in Kochi backwaters, Estuar. Coast. Shelf. Sci., 78, 291-300, 2008.

Morrison, J. M., Codispoti, L. A., Smith, S. L., Wishner, K., Flagg, C., Gardner, W. D., Gaurin, S., Naqvi, S. W. A., Manghnani, V., and Prosperie, L.: The oxygen minimum zone in the Arabian sea during 1995, Deep-Sea. Res. II, 46, 1903-1931, 1999.

Naqvi, S. W. A. and Qasim, S. Z.: Inorganic nitrogen \& nitrate reduction in the Arabian Sea, Indian J. Mar. Sci., 12, 21-26, 1983.

Naqvi, S. W. A., Jayakumar, D. A., Narvekar, P. V., Naik, H., Sarma, V., D'Souza, W., Joseph, S., and George, M. D.: Increased marine production of $\mathrm{N}_{2} \mathrm{O}$ due to intensifying anoxia on the Indian continental shelf, Nature, 408, 346-349, 2000.

Naqvi, S. W. A. and Jayakumar, D. A.: Ocean biogeochemistry and atmospheric composition: Significance of the Arabian Sea, Curr. Sci., 78, 289-299, 2000a.

Naqvi, S. W. A., Bange, H. W., Gibb, S. W., Goyet, C., Hatton, A. D., and Upstill-Goddard, R. C.: Biogeochemical ocean-atmosphere transfers in the Arabian sea, Prog. Oceanogr., 65, $20 \quad 116-144,2005$.

Naqvi, S. W. A., Naik, H., Jayakumar, D. A., Shailaja, M. S., and Narvekar, P. V.: Seasonal oxygen deficiency over the western continental shelf of India, Past and Present Water Column Anoxia, Neretin, L. N. (NATO Sci. Ser. IV: Earth and Environ. Sci; 64), Springer, Dordrecht, The Netherlands, 195-224, 2006.

25 Nevison, C. D., Weiss, R. F., and Erickson III, D. J.: Global oceanic emissions of nitrous oxide, J. Geophys. Res., 100(C8), 15809-15820, 1995.

Olson, R. J.: Differensial poto-inhibition of marine nitrifying bacteria : A possible mechanisam for the formation of primary nitrite maximum, J. Mar. Res., 39, 227-238, 1981.

Purnachandra Rao, V., Nair, R. R., and Hashimi, N. H.: Clay mineral distribution on the Kerala continental shelf and slope, J. Geol. Soc. India., 24, 540-546, 1983.

Qasim, S. Z. and Gopinatan, C. K.: Tidal cycle and environmental features of Cochin backwaters, a tropical estuary, Proceedings in the Indian Accedamy of Science, 69, 336-348, 1969.

1769

Qasim, S. Z.: Indian estuaries, Allied Publishers, Heriedia Marg, Ballard Estate, Mumbai, 259 pp., 2003.

Rabouille, C., Conley, D. J., Dai, M. H., Cai, W. J., Chen, C. T. A., Lansard, B., Green, R., Yin, K., Harrison, P. J., and Dagg, M.: Comparison of hypoxia among four river-dominated ocean

5 margins: The changjiang (Yangtze), Mississippi, pearl, and Rhone rivers, Cont. Shelf. Res., 28, 1527-1537, 2008.

Ramalingeswara Rao, B. and Veerayya, M.: Influence of marginal highs on the accumulation of organic carbon along the continental slope off western India, Deep-Sea. Res. II, 47, 303$327,2000$.

10 Ramamirtham, C. P. and Jayaraman, R.: Some aspects of the hydrological conditions of the backwaters around Willington Island, Cochin, J. Mar. Biol. Ass. India., 5, 170-177, 1963.

Ramamirtham, C. P. and Muthusamy, S.: Estuarine oceanography of the Vembanad Lake. Part II: The region between Cochin and Azhikode, Indian. J. Fish., 33, 218-224, 1986.

Raymond, P. A. and Bauer, J. E.: Riverine export of aged terrestrial organic matter to the North Atlantic Ocean, Nature, 409, 497-500, 2001.

Ritter, C. and Montagna, P. A.: Seasonal hypoxia and models of benthic response in a Texas Bay, Estuaries, 22, 7-20, 1999.

Ryther, J. H.: Photosynthesis and fish production in the sea, Science, 166, 72-76, 1969.

Sankaranarayanan, V. N. and Qasim, S. Z.: Nutrients in the Cochin backwaters in relation to environmental characteristics, Mar. Biol., 2, 236-245, 1969.

Sheeba, P.: Distribution of benthic Infauna in the Cochin backwaters in relation to environmental parameters, Ph.D Thesis, Cochin University of Science and Technology, Cochin, 241 pp. online available at: http://dyuthi.cusat.ac.in/dspace/handle/123456789/105, 2000.

Shetye, S. R., Gouveia, A. D., Shenoi, S. S. C., Sundar, D., Michael, G. S., Almeida, A. M., and

25 Santanam, K.: Hydrography and circulation off the west coast of India during the southwest monsoon 1987, J. Mar. Res., 48, 359-378, 1990.

Soman, K.: Geology of Kerala, Geological Society of India, Bangalore, 278 pp., 1997.

Srinivas, K. and Dinesh Kumar, P. K.: Atmospheric forcing on the seasonal variability of sea level at Cochin, southwest coast of India, Cont. Shelf. Res., 26, 1113-1133, 2006.

30 Srinivas, K., Revichandran, C., Maheswaran, P. A., Asharaf, T. T. M., and Murukesh, N.: Propagation of tides in the Cochin estuarine system, southwest coast of India, Indian. J. Mar. Sci., 32, 14-24, 2003.

Strickland, J. D. H. and Parsons, T. R.: A practical handbook of seawater analysis.: Fisheries 
research board of Canada, Bulletin 167, Ottawa 1972 (repr. 1977), 1972.

Thomson, K. T.: Economic and Social Issues of Biodiversity Loss In Cochin Backwaters, Technical Report, Cochin University of Science and Technology, Cochin, 51-82, 2002.

Thottathil, S. D., Balachandran, K. K., Gupta, G. V. M., Madhu, N. V., and Nair, S.: Influence of

5 allochthonous input on autotrophic-heterotrophic switch-over in shallow waters of a tropical estuary (cochin estuary), India, Estuar. Coast. Shelf. Sci., 78, 551-562, 2008.

Udaya Varma, P., Abraham, P., and Ramaraju, V. S.: Tidal influence on the seasonal variation in current and salinity around Willington Island, Mahasagar, 4(4), 225-237, 1981.

Unnithan, R. V., Vijayan, M., and Remani, K. N.: Organic pollution in Cochin backwaters, Indian. J. Mar. Sci., 4, 39-42, 1975.

Vijayalakshmi, G. S. and Venugopalan, V. K.: Diurnal variations in the physio-chemical and biological properties in the Vellar estuary, Indian. J. Mar. Sci., 1, 125-127, 1973.

Zhang, G., Zhang, J., Xu, J., and Zhang, F.: Distributions, sources and atmospheric fluxes of nitrous oxide in Jiaozhou bay, Estuar. Coast. Shelf. Sci., 68, 557-566, 2006.

15 Zillén, L., Conley, D. J., Andrén, T., Andrén, E., and Björck, S.: Past occurrences of hypoxia in the Baltic sea and the role of climate variability, environmental change and human impact, Earth-Sci. Rev., 91, 77-92, 2008.

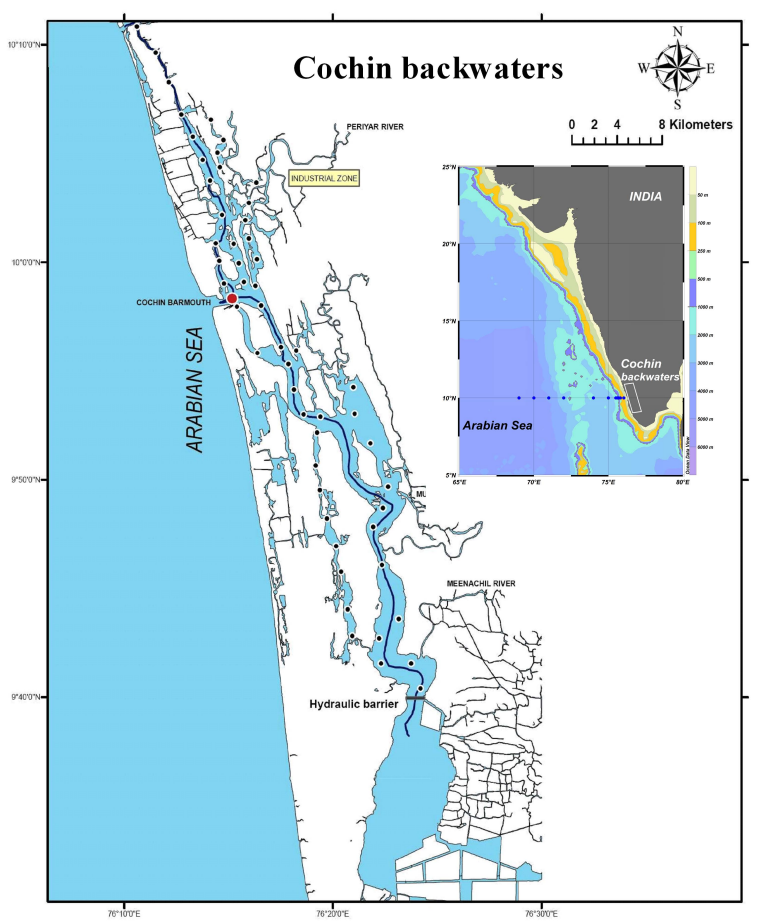

Fig. 1. Location of the sampling sites in the Cochin backwaters and adjacent coastal waters. 

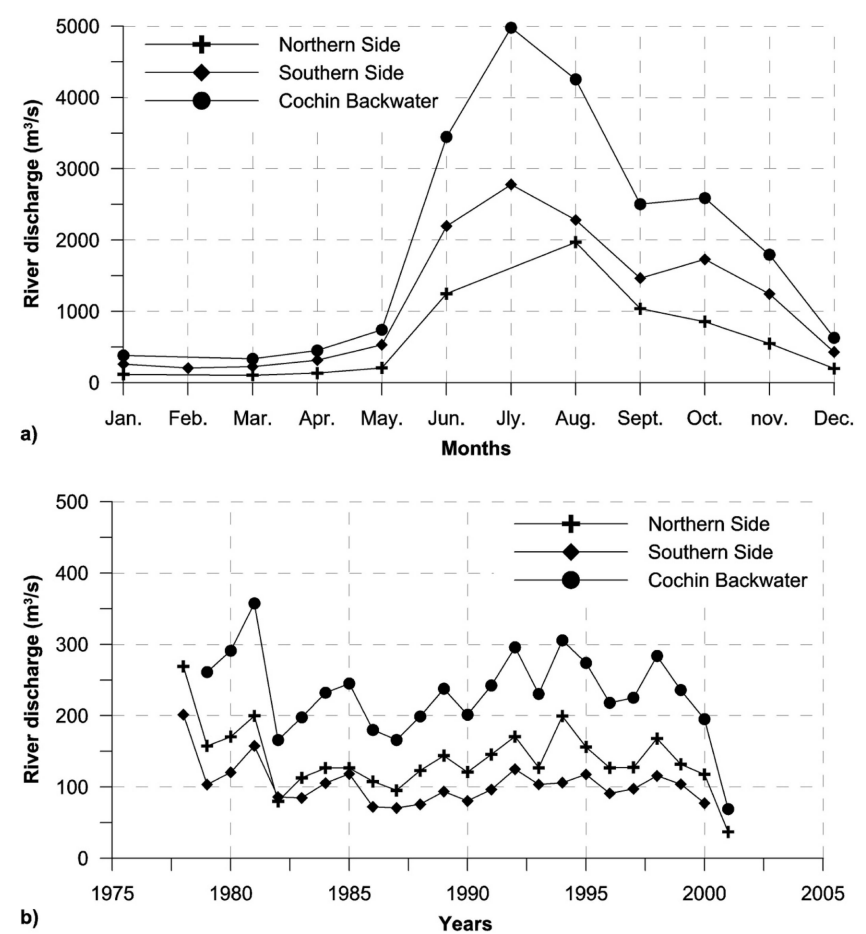

Fig. 2. (a) Climatology of river discharge (1978-2002) in the Cochin backwaters. (b) Long term variations in the river discharge into the Cochin backwaters.
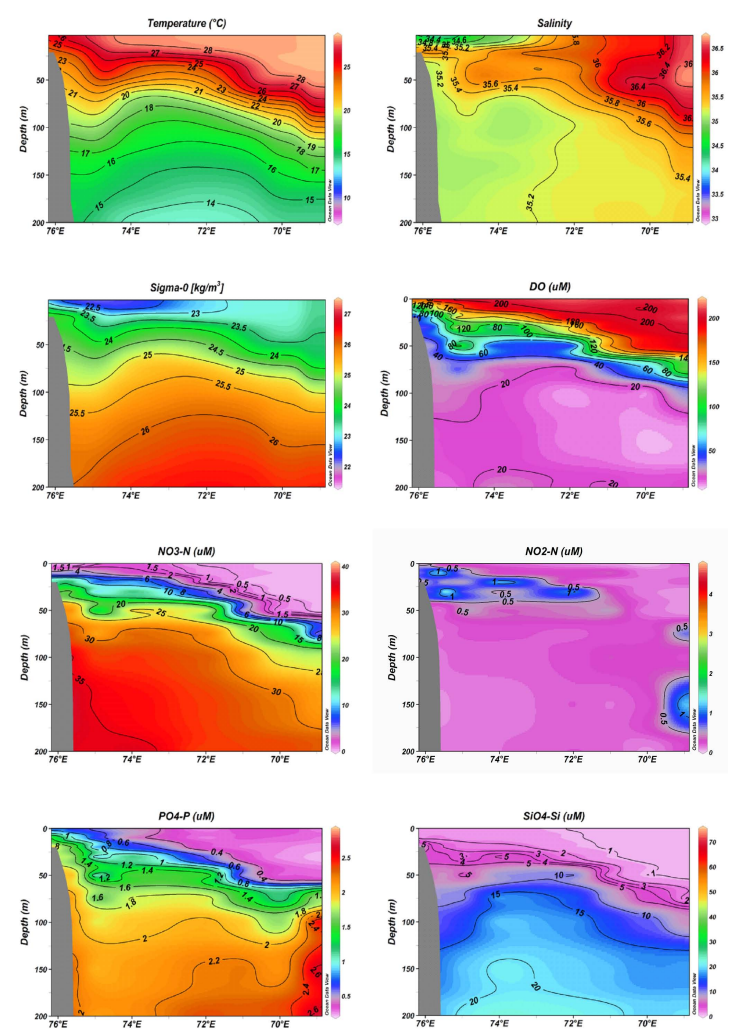

Fig. 3. Map showing the hydrographic distribution of physico-chemical parameters (Temperature, Salinity, Density, Dissolved Oxygen, Nitrate, Nitrite, Phosphate and Silicate) in the coastal waters. 

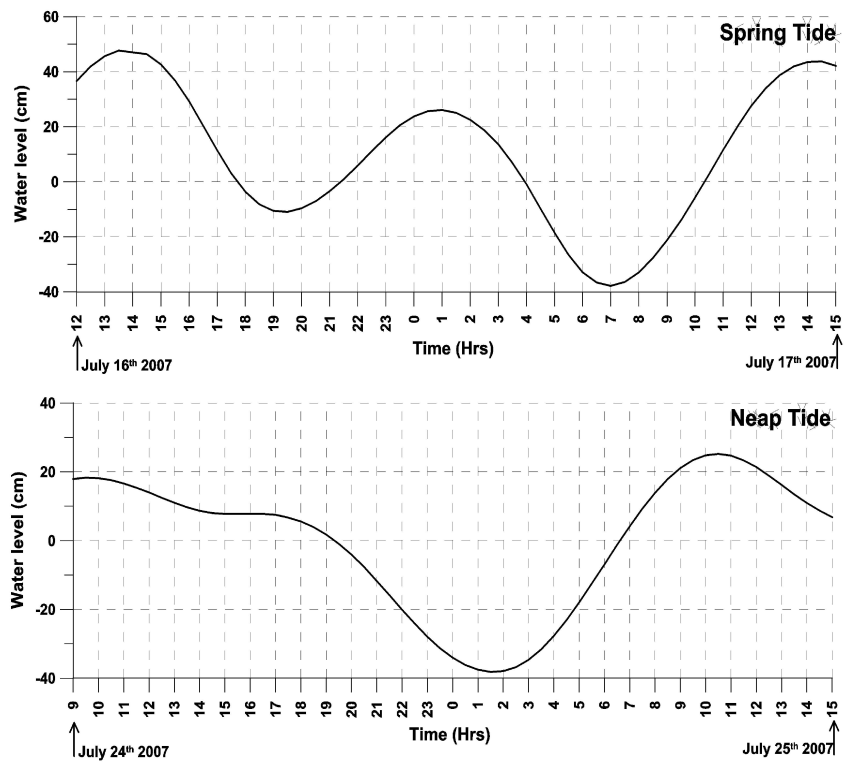

Fig. 4a. Diurnal variation of water level in the Cochin backwaters during spring and neap phase.
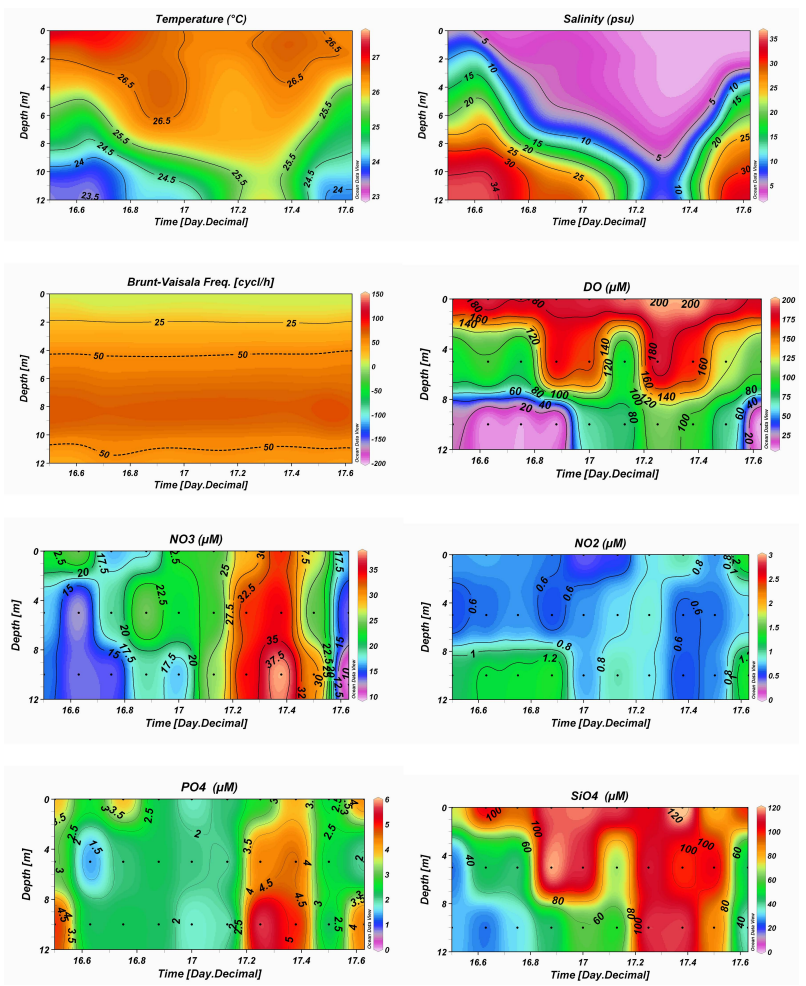

Fig. 4b. Diurnal variation of physico-chemical parameters (Temperature, Salinity, Brunt-Vaisala Frequency, Dissolved Oxygen, Nitrate, Nitrite, Phosphate and Silicate) in the Cochin backwater during spring phase. 

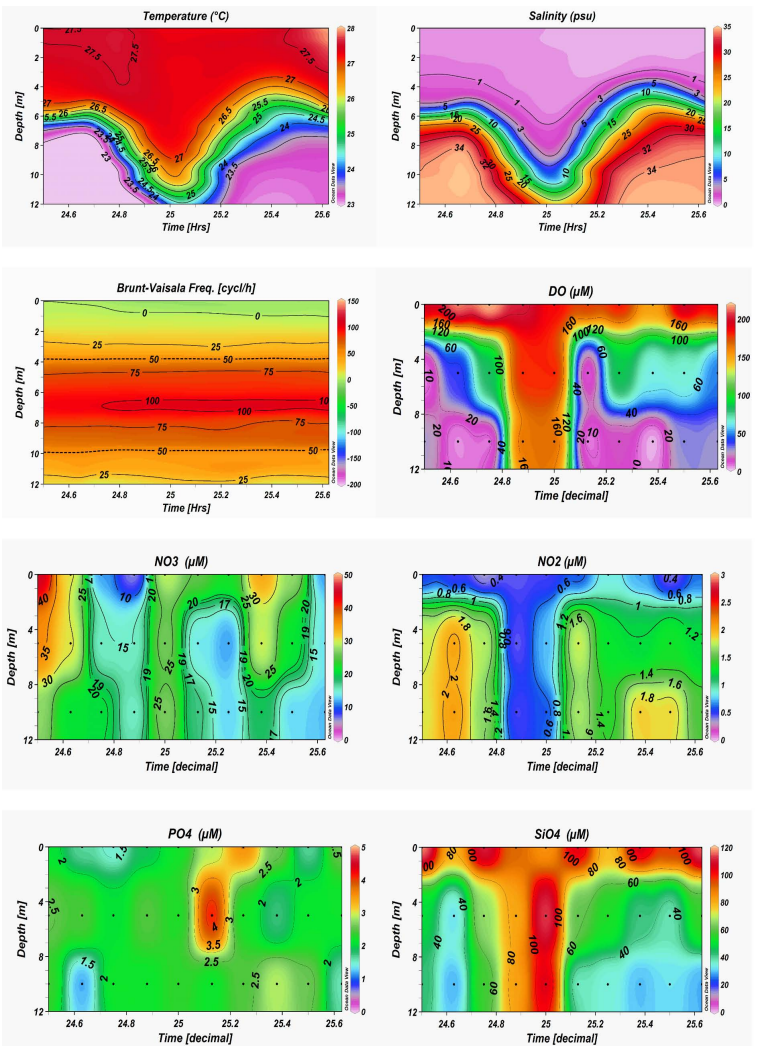

Fig. 4c. Diurnal variation of physico-chemical parameters (Temperature, Salinity, Brunt-Vaisala Frequency, Dissolved Oxygen, Nitrate, Nitrite, Phosphate and Silicate) in the Cochin backwater during neap phase.

1777

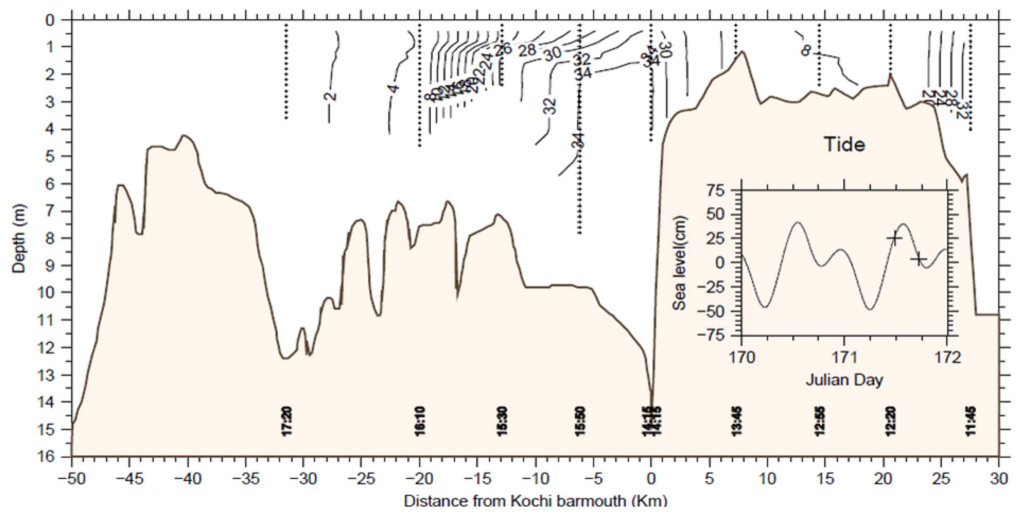

Fig. 5a. Intrusion of saline waters in to Cochin backwaters during spring phase. 


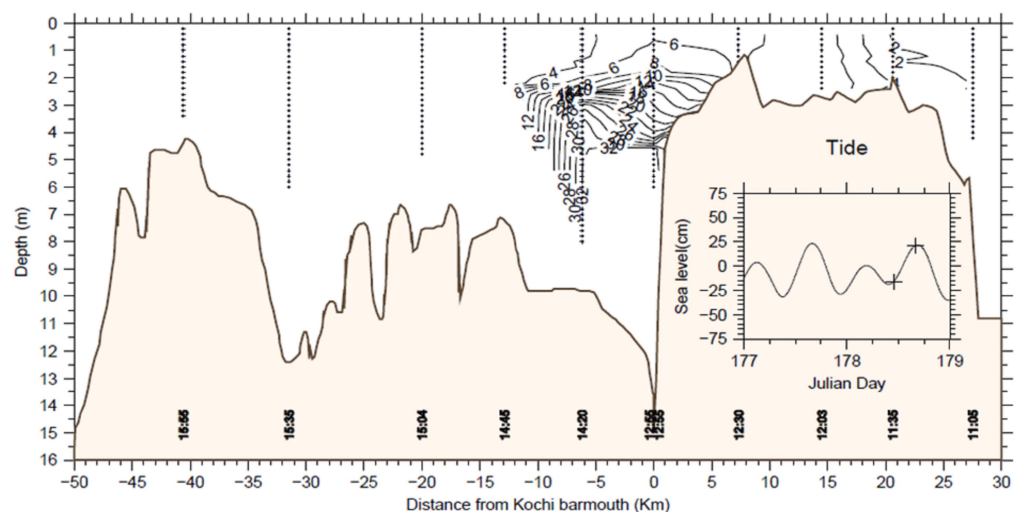

Fig. 5b. Intrusion of saline waters in to Cochin backwaters during neap phase.
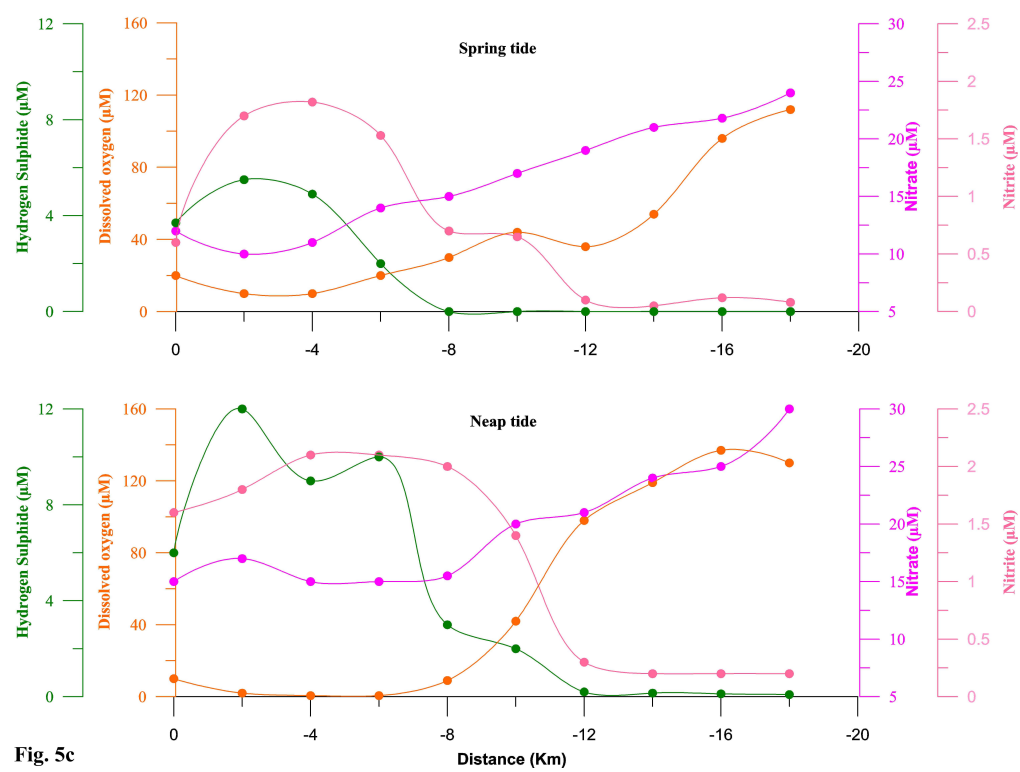

Fig. 5c. Variation in the Dissolved Oxygen, Nitrate, Nitrite and Hydrogen Sulphide during spring and neap phase in the Cochin backwaters. 


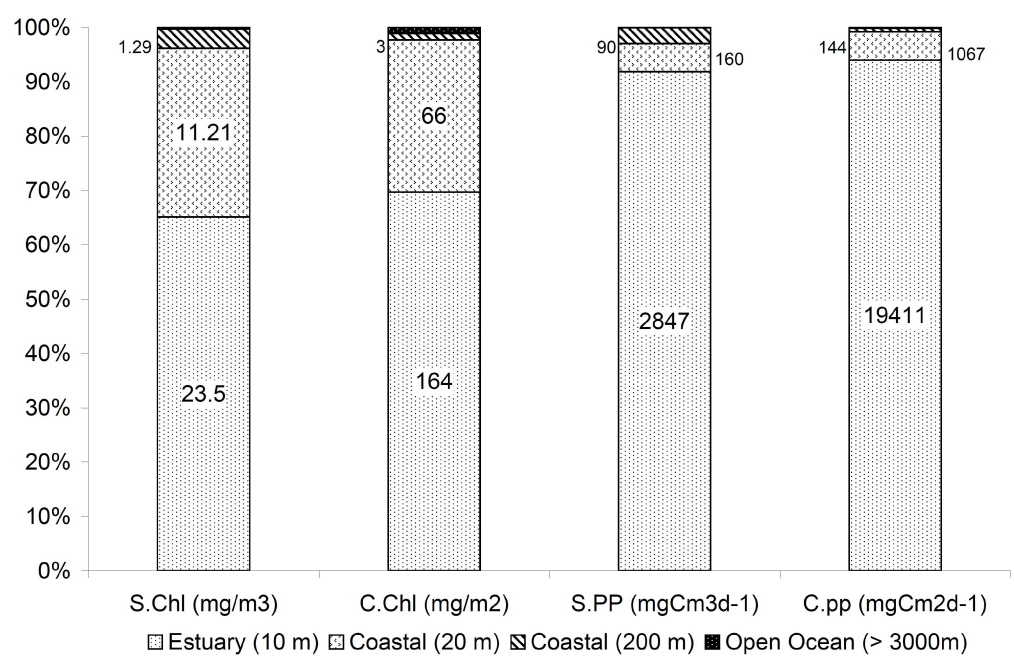

Fig. 6. Variation in the chlorophyll $a$ and primary production in the Cochin backwaters, coastal and open ocean waters.

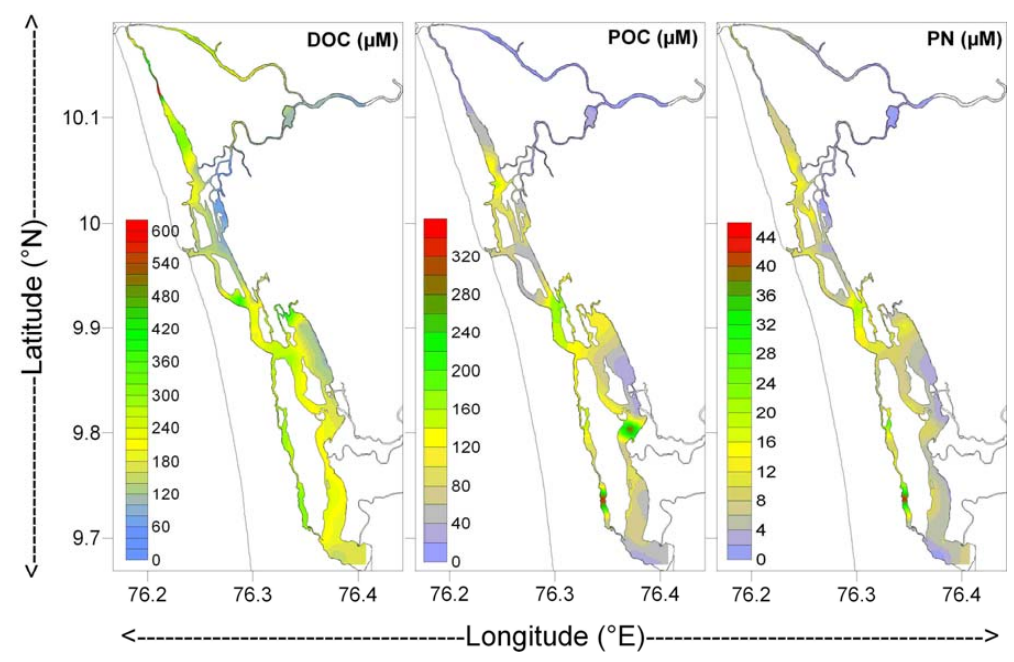

Fig. 7. Distribution of Dissolved Organic Carbon (DOC), Particulate Organic Carbon (POC), Particulate Nitrogen (PN) in the Cochin backwaters. 